\title{
Infrared and Raman spectroscopic studies of glasses with NASICON-type chemistry
}

\author{
K J RAO*, K C SOBHA and SUNDEEP KUMAR \\ Solid State and Structural Chemistry Unit, Indian Institute of Science, \\ Bangalore 560 012, India \\ e-mail: kjrao@sscu.iisc.ernet.in
}

\begin{abstract}
Structures of NASICON glasses of the general formula $\mathrm{AB}_{2}\left(\mathrm{PO}_{4}\right)_{3}$, where $\mathrm{A}=\mathrm{Li}, \mathrm{Na}$ or $\mathrm{K}$ and $\mathrm{B}=\mathrm{Fe}, \mathrm{Ga}, \mathrm{Ti}, \mathrm{V}$ or $\mathrm{Nb}$, have been investigated using vibrational (IR and Raman) spectroscopies. Phosphate species appear to establish an equilibrium via a disproportionation reaction involving a dynamical bond-switching mechanism where both charge and bonds are conserved. B ions in the system acquire different coordinations to oxygens. Alkali ions cause absorptions due to cage vibrations. All the observed spectroscopic features are consistent with speciation involving disproportionation reactions.
\end{abstract}

Keywords. NASICON glasses; dynamical bond-switching mechanism; disproportionation reactions.

\section{Introduction}

NASICON is the acronym ${ }^{1,2}$ for 'sodium super ionic conductors' in the crystalline state with the general formula $\mathrm{AB}_{2}\left(\mathrm{PO}_{4}\right)_{3}$, where $\mathrm{A}$ is an alkali ion and $\mathrm{B}$ is generally a metal with a valency of 4 or more, but is also substitutable by trivalent elements. Crystalline NASICONs generally possess a rhombohedral $R \overline{3} c$ structure, in which $\mathrm{BO}_{6}$ octahedra share corners with $\mathrm{PO}_{4}$ tetrahedra. NASICONs possess 'open' structures in which alkali ions can move with significantly reduced activation barriers and hence the potential for applications as fast ion conductors. Since the B site can be substituted by a variety of transition and non-transition metals (and their combinations) with appropriate charge compensation in the structure by additional alkali ions, NASICONs constitute a very versatile class of materials ${ }^{3-5}$.

NASICONs by virtue of their complex chemistry have a built-in propensity to form good glasses, (especially when the material is a phosphate). Higher valent elements such as vanadium $(\mathrm{V})$ or niobium $(\mathrm{Nb})$ increase the covalency of the $\mathrm{B}-\mathrm{O}$ linkage and facilitate the formation of glasses. A number of NASICON glasses have been investigated ${ }^{6-9}$ in this laboratory. It has been found that contrary to expectations, the molar volumes of glasses with NASICON chemistry are sensitive to the size of the alkali ion to a much greater extent than their crystalline counterparts. Indeed, in the absence of the requirement of crystalline periodicity, the network structure collapses around the alkali ions, eliminating the 'openness' of the structure, and the observed conductivities are rather low. Additionally, the coordination numbers of the B ions also vary, facilitating the formation of different types of phosphate species, which have been identified ${ }^{10}$ by ${ }^{31} \mathrm{P}$ MAS NMR.

*For correspondence 
Vibrational spectroscopic studies provide crucial structural information in glassy materials. In our earlier investigations ${ }^{6-10}$, we suggested that the structure of the NASICON glasses consists of a weak polymeric network of $\left[\mathrm{POO}_{m / 2} \mathrm{O}_{k}\right]^{k-}$ and $\left[\mathrm{BO}_{l / 2}\right]^{n-}$ and $\mathrm{A}^{+}$ions where $m$ is the number of bridging oxygens connected to phosphorus which is always four coordinated but $m(\leq 3)$-connected, $k=3-m, l$ is the coordination number of $\mathrm{B}$ and $n=l-$ valency of $\mathrm{B}$. Molar volumes of these glasses change considerably upon interalkali substitution for the same B ion, suggesting that the A cations do not simply occupy designated spaces (like A sites in crystalline NASICON's ${ }^{1,11}$ ) present in a structural framework, but are surrounded at close-packing distances by oxygens so as to optimize the volume. The glass transition temperatures $\left(T_{g}\right)$ of the NASICON glasses occur within a narrow range of $30 \mathrm{~K}$, when the $\mathrm{B}$ ion is fixed irrespective of the alkali ion. Therefore $T_{g}$ is likely to be determined by the vibrational properties of alkali ions in these glasses unlike in the several systems we have examined ${ }^{12}$. Therefore, the anion framework is likely to play an important role in determining the properties of the glasses with NASICON chemistry. It appears that the low dimensionality caused by the alkali modification and network flexibility enables the polymeric network to provide close coordinations to alkali ions, whereas the glass transition behaviour is determined by segmental motions of the anion framework which is constituted of $\left[\mathrm{POO}_{m / 2} \mathrm{O}_{k}\right]^{k-}$ and $\left[\mathrm{BO}_{l / 2}\right]^{n-}$ units. These units possess characteristic vibrational features and infrared (IR) and Raman spectroscopies are particularly suited for their investigation. Very few reports have appeared in the literature on the vibrational spectra of this class of phosphate glasses. Some of the reported spectra refer to either a single glass composition or to the study of the systematic variation of composition with respect to one of the constituent oxides ${ }^{13-17}$.

We have therefore examined vibrational spectra of several glasses with NASICON chemistry. The spectra of a few crystalline NASICONs have also been studied in order to provide a comparison between the spectra of glasses and crystals of the same composition. Our findings are presented in this paper and discussed.

\section{Experimental}

Infrared transmission spectra of the glasses and crystals were recorded from 4000 to $200 \mathrm{~cm}^{-1}$ using a Perkin-Elmer 580 double beam IR spectrometer. IR spectra of the crystalline compounds and the glasses were recorded in $\mathrm{KBr}$ pellets. The Fourier transform IR (FTIR) spectra were recorded using a Bruker IFS 113 FTIR spectrometer. Mixtures of the glass powder and polyethylene were pelletized and used for recording the FTIR spectra. Unpolarized Raman spectra were recorded on a Spex 1403 Raman spectrometer making use of the excitation wavelength of $514.5 \mathrm{~nm}$ from an Argon ion laser (Spectra-Physics Series 2000). Polished faces of the pellets of the compounds and small rectangular, polished glass pieces or glass compacts (when large bits could not be obtained) were used for the Raman measurements. All the spectra have been recorded at room temperature $(293 \mathrm{~K})$.

\section{Results and discussion}

\subsection{Crystalline NASICON compounds}

The compounds whose vibrational spectra have been studied here are $\mathrm{Na}_{5} \mathrm{ZrP}_{3} \mathrm{O}_{12}$, $\mathrm{Na}_{5} \mathrm{TiP}_{3} \mathrm{O}_{12}, \mathrm{Na}_{3} \mathrm{Fe}_{2} \mathrm{P}_{3} \mathrm{O}_{12}$ and $\mathrm{Na}_{4} \mathrm{NbP}_{3} \mathrm{O}_{12}$. 
3.1a Infrared studies: IR spectra of crystalline $\mathrm{Na}_{3} \mathrm{Fe}_{2} \mathrm{P}_{3} \mathrm{O}_{12}, \mathrm{Na}_{5} \mathrm{ZrP}_{3} \mathrm{O}_{12}, \mathrm{Na}_{5} \mathrm{TiP}_{3} \mathrm{O}_{12}$ and $\mathrm{Na}_{4} \mathrm{NbP}_{3} \mathrm{O}_{12}$ are given in figure 1. Spectra of these crystalline compounds have been examined for comparison with the spectra of glasses. IR spectra of $\mathrm{Na}_{5} \mathrm{ZrP}_{3} \mathrm{O}_{12}$ or $\mathrm{Na}_{5} \mathrm{TiP}_{3} \mathrm{O}_{12}$ both with $R 32$ structure ${ }^{11,15}$ have more features than those of $\mathrm{NaZr}_{2} \mathrm{P}_{3} \mathrm{O}_{12}$ and similar compounds with $R \overline{3} c$ structure ${ }^{18}$ (analysed in detail by Barj et al ${ }^{19,20}$ and Tarte et $a l^{21}$ ), particularly in the region above $900 \mathrm{~cm}^{-1}$ owing to greater distortion of $\mathrm{PO}_{4}$ tetrahedra. In the compounds $\mathrm{Na}_{5} \mathrm{ZrP}_{3} \mathrm{O}_{12}$ and $\mathrm{Na}_{5} \mathrm{TiP}_{3} \mathrm{O}_{12}$, half of the $\mathrm{B}$ sites are occupied by $\mathrm{Na}(\mathrm{A})$ atoms, which lowers the symmetry of the $\mathrm{PO}_{4}$ ion from $T_{d}$ to $C_{2}$. The internal modes of the $\mathrm{PO}_{4}$ ion are obtained using factor group analysis (table 1): 5 asymmetric stretching, 1 symmetric stretching, 5 asymmetric bending and 2 symmetric

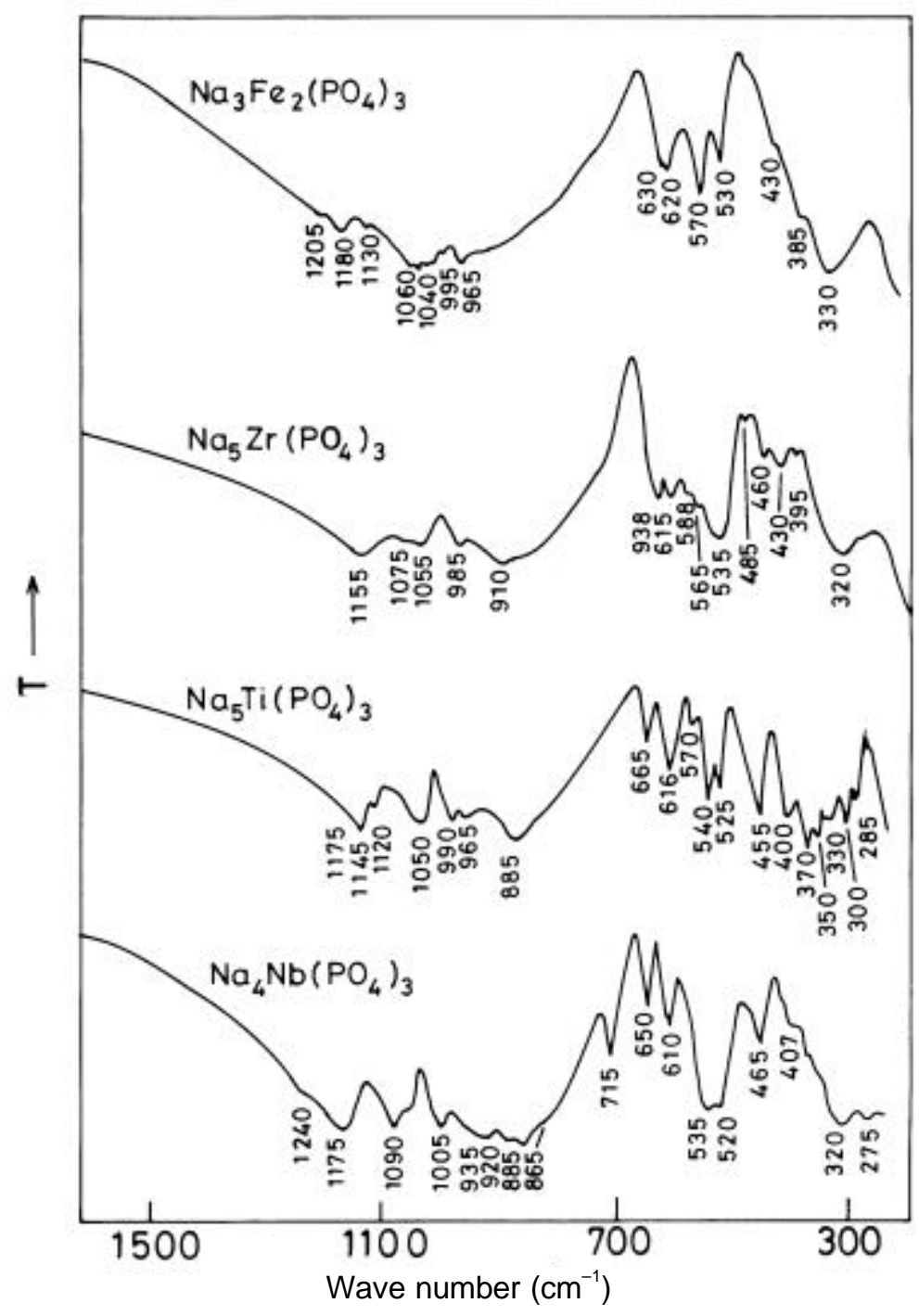

Figure 1. IR absorption spectra of crystalline NASICON compounds. 
Table 1. Factor group analysis of the phosphate modes in $\mathrm{Na}_{5} \mathrm{TiP}_{3} \mathrm{O}_{12}$.

IR active modes: $E\left(v_{1}\right), 2 E\left(v_{2}\right), 2 A_{2}+3 E\left(v_{3}, v_{4}\right)$

Raman active modes: $A_{1}\left(v_{1}\right), 2 A_{1}\left(v_{2}\right), 2 A_{2}+3 E+A_{1}\left(v_{3}, v_{4}\right)$.

\begin{tabular}{llll}
\hline & Point group $T_{d}$ & Site group $C_{2}$ & Factor group $D_{3}$ \\
\hline$v_{1}$ & $A_{1}(\mathrm{R})$ & $A$ & $A_{1}+E$ \\
$\mathrm{v}_{2}$ & $E(\mathrm{R})$ & $2 A$ & $2 A_{1}+2 E$ \\
$\mathrm{v}_{3}, \mathrm{v}_{4}$ & $F_{2}(\mathrm{IR}, \mathrm{R})$ & $A+2 B$ & $A_{1}+3 E+2 A_{2}$ \\
\hline
\end{tabular}

bending modes of the $\mathrm{PO}_{4}$ group to be infrared active. We may tentatively assign the infrared bands of $\mathrm{Na}_{5} \mathrm{TiP}_{3} \mathrm{O}_{12}$ (figure 1) between 1175 and $885 \mathrm{~cm}^{-1}$ to the asymmetric (5 bands) and symmetric ( 1 band) stretching, $655-525 \mathrm{~cm}^{-1}$ to the asymmetric bending ( 5 bands) and $455-400 \mathrm{~cm}^{-1}$ to the symmetric bending ( 2 bands) of the $\mathrm{PO}_{4}$ unit. The bands below $370 \mathrm{~cm}^{-1}$ probably involve modes of complex nature including external modes and cage vibrations of alkali ions. Similar assignments hold good for the IR spectrum of $\mathrm{Na}_{5} \mathrm{ZrP}_{3} \mathrm{O}_{12}$.

3.1b Raman spectrum: Raman spectra of crystalline $\mathrm{Na}_{3} \mathrm{FeP}_{3} \mathrm{O}_{12}$ and $\mathrm{Na}_{5} \mathrm{TiP}_{3} \mathrm{O}_{12}$ are given in figure 2. The Raman bands between $1157-891 \mathrm{~cm}^{-1}$ are assigned to the stretching modes ( 7 bands are expected), the 6 weak bands around $590 \mathrm{~cm}^{-1}$ to the asymmetric bending and the 460 and $436 \mathrm{~cm}^{-1}$ bands to the symmetric bending modes of $\mathrm{PO}_{4}$ ion. But the $590 \mathrm{~cm}^{-1}$ band could also arise from the vibrations of $\mathrm{TiO}_{6}$ octahedra. The bands below $436 \mathrm{~cm}^{-1}$ may again involve external modes of the $\mathrm{PO}_{4}$ and modes arising from $\left[\mathrm{FeO}_{6}\right]$ and $\left[\mathrm{TiO}_{6}\right]$ groups.

$\mathrm{Na}_{3} \mathrm{Fe}_{2} \mathrm{P}_{3} \mathrm{O}_{12}$ has a structure similar to that of $\mathrm{NaZr}_{2} \mathrm{P}_{3} \mathrm{O}_{12}$, except that two more A ion sites are occupied. The room temperature structure of $\mathrm{Na}_{3} \mathrm{Fe}_{2} \mathrm{P}_{3} \mathrm{O}_{12}$ ( $\left.\boldsymbol{\alpha} \kappa \mathrm{NFP}\right)$ is monoclinic and complex ${ }^{22}$ and has not been well-characterized. Therefore, spectroscopic assignments are even more difficult for this compound. However, it can be seen that the number of bands are few, though the bands are broad. The structure of $\mathrm{Na}_{4} \mathrm{NbP}_{3} \mathrm{O}_{12}$ is also not known clearly. However, the bands at $1240 \mathrm{~cm}^{-1}$ (generally considered as due to $\mathrm{P}=\mathrm{O}$ stretching) and at $715 \mathrm{~cm}^{-1}$ (which is usually assigned to $\mathrm{P}-\mathrm{O}-\mathrm{P}$ stretching) ${ }^{23}$ found in the spectrum of $\mathrm{Na}_{4} \mathrm{NbP}_{3} \mathrm{O}_{12}$, are absent in the crystalline $\mathrm{Na}_{3} \mathrm{Fe}_{2} \mathrm{P}_{3} \mathrm{O}_{12}, \mathrm{Na}_{5} \mathrm{ZrP}_{3} \mathrm{O}_{12}$ or $\mathrm{Na}_{5} \mathrm{TiP}_{3} \mathrm{O}_{12}$ which suggests that the structure of $\mathrm{Na}_{4} \mathrm{NbP}_{3} \mathrm{O}_{12}$ is likely to be different from that of the other crystalline phases. Here again a number of studies ${ }^{19-21}$ suggest that the low frequency bands could be associated with external modes involving motions of octahedra centered around B ions. The somewhat prominent IR absorption band below $300 \mathrm{~cm}^{-1}$, particularly in $\mathrm{Na}^{+}$ion-rich compounds could be associated with vibrations of $\mathrm{Na}^{+}$ions in oxygen cages ${ }^{24}$.

\subsection{Glasses}

Spectroscopic investigations have been carried out on the various glass compositions. Since they are glasses, their compositions can be expressed in terms of the component oxides. This enables us to view glasses as $\mathrm{BO}_{n}-\mathrm{P}_{2} \mathrm{O}_{5}$ networks modified by the alkali oxides and therefore identify the structural units expected to be present in each system. This information is summarized in table 2. There are three types of glass compositions: (1) $3 \mathrm{~A}_{2} \mathrm{O}-2 \mathrm{~B}_{2} \mathrm{O}_{3}-3 \mathrm{P}_{2} \mathrm{O}_{5}$, where $\mathrm{B}=\mathrm{Fe}$ or $\mathrm{Ga}$; (2) $5 \mathrm{~A}_{2} \mathrm{O}-2 \mathrm{BO}_{2}-3 \mathrm{P}_{2} \mathrm{O}_{5}$ where $\mathrm{B}=\mathrm{Ti}$ or $\mathrm{Ge}$ 


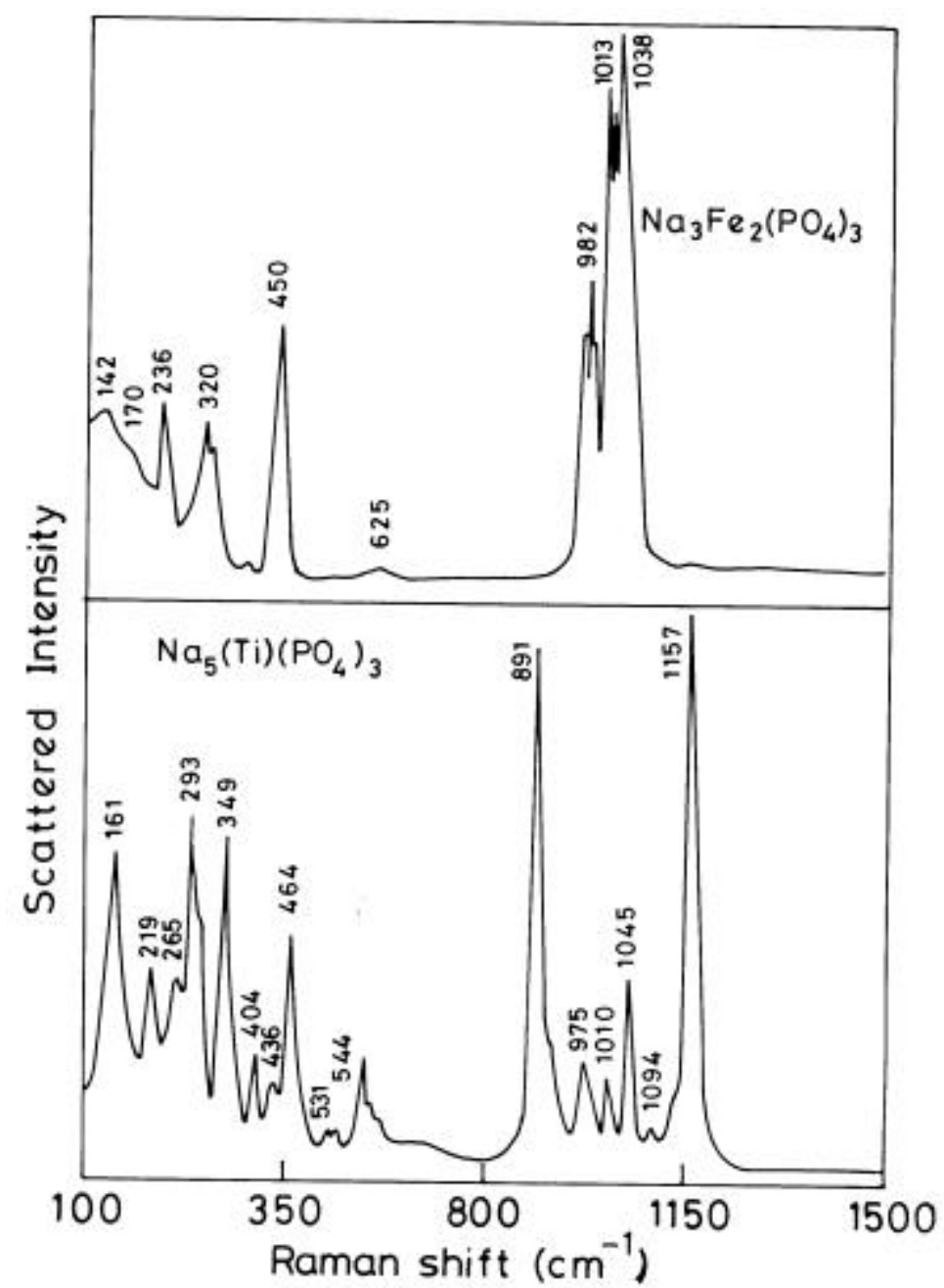

Figure 2. Raman spectra of crystalline $\mathrm{Na}_{3} \mathrm{Fe}_{2}\left(\mathrm{PO}_{4}\right)_{3}$ and $\mathrm{Na}_{5} \mathrm{Ti}\left(\mathrm{PO}_{4}\right)_{3}$.

and (3) $4 \mathrm{~A}_{2} \mathrm{O}-\mathrm{B}_{2} \mathrm{O}_{5}-3 \mathrm{P}_{2} \mathrm{O}_{5}$, where $\mathrm{B}=\mathrm{V}$ or $\mathrm{Nb}$; for $\mathrm{A}=\mathrm{Li}, \mathrm{Na}$ or $\mathrm{K}$ in all these glasses. Thus the three series are based on the (dominant) valency of the $\mathrm{B}$ ion. The spectra are discussed below keeping in view this chemical distinction.

3.2a Infrared spectra: The IR absorption spectra of three series of glasses from 1500 to $300 \mathrm{~cm}^{-1}$ are shown in figures 3-5. IR absorption bands of phosphates are not known to appear above $1300 \mathrm{~cm}^{-1}$. The entire region down to $400 \mathrm{~cm}^{-1}$ is dominated by the vibrations of the $\mathrm{PO}_{4}$ tetrahedra. Comparing with the band positions in the crystalline compounds discussed earlier, we can assign the broad band between $1200 \mathrm{~cm}^{-1}$ and $890 \mathrm{~cm}^{-1}$ to the asymmetric and symmetric stretching modes, the band centred at $600 \mathrm{~cm}^{-1}$ to the asymmetric bending modes and the weak band near $470 \mathrm{~cm}^{-1}$ to the symmetric bending modes of the $\mathrm{PO}_{4}$ tetrahedra. 
Table 2. Glass composition, spectroscopic investigation conducted and the structural units expected to be found in the glass.

\begin{tabular}{|c|c|c|c|}
\hline $\begin{array}{l}\text { Compd } \\
\text { no. }\end{array}$ & $\begin{array}{l}\text { Composition } \\
\text { and designation }\end{array}$ & $\begin{array}{l}\text { Spectroscopic } \\
\text { investigation }\end{array}$ & $\begin{array}{c}\text { Possible structural units, } \\
\text { A=Li, } \mathrm{Na} \text { or } \mathrm{K}\end{array}$ \\
\hline $\begin{array}{l}1 \\
2 \\
3\end{array}$ & $\begin{array}{l}\mathrm{Li}_{3} \mathrm{Fe}_{2} \mathrm{P}_{3} \mathrm{O}_{12} \text { (LFP) } \\
\mathrm{Na}_{3} \mathrm{Fe}_{2} \mathrm{P}_{3} \mathrm{O}_{12} \text { (NFP) } \\
\mathrm{K}_{3} \mathrm{Fe}_{2} \mathrm{P}_{3} \mathrm{O}_{12} \text { (KFP) }\end{array}$ & $\begin{array}{l}\text { IR, FTIR } \\
\text { IR, R, FTIR } \\
\text { IR, FTIR }\end{array}$ & $\begin{array}{l}3 \mathrm{~A}^{+}+2\left[\mathrm{FeO}_{4 / 2}\right]^{-}+2\left[\mathrm{POO}_{3 / 2}\right]+1\left[\mathrm{POO}_{2 / 2} \mathrm{O}\right]^{-} \\
3 \mathrm{~A}^{+}+2 \mathrm{Fe}^{3+}+3\left[\mathrm{PO}_{4}\right]^{3-}\end{array}$ \\
\hline $\begin{array}{l}4 \\
5\end{array}$ & $\begin{array}{l}\mathrm{Na}_{3} \mathrm{Ga}_{2} \mathrm{P}_{3} \mathrm{O}_{12}(\mathrm{NGP}) \\
\mathrm{K}_{3} \mathrm{Ga}_{2} \mathrm{P}_{3} \mathrm{O}_{12}(\mathrm{KGP})\end{array}$ & $\begin{array}{l}\text { IR, FTIR } \\
\text { IR, R, FTIR }\end{array}$ & $3 \mathrm{~A}^{+}+2\left[\mathrm{GaO}_{4 / 2}\right]^{-}+2\left[\mathrm{POO}_{3 / 2}\right]+1\left[\mathrm{POO}_{2 / 2} \mathrm{O}\right]^{-}$ \\
\hline $\begin{array}{l}6 \\
7 \\
8\end{array}$ & $\begin{array}{l}\mathrm{Li}_{5} \mathrm{TiP}_{3} \mathrm{O}_{12}(\mathrm{LTP}) \\
\mathrm{Na}_{5} \mathrm{TiP}_{3} \mathrm{O}_{12} \text { (NTP) } \\
\mathrm{K}_{5} \mathrm{TiP}_{3} \mathrm{O}_{12} \text { (KTP) }\end{array}$ & $\begin{array}{l}\text { IR, R, FTIR } \\
\text { IR, R, FTIR } \\
\text { IR, FTIR }\end{array}$ & $\begin{array}{l}5 \mathrm{~A}^{+}+\left[\mathrm{TiO}_{4 / 2}\right]^{0}+2\left[\mathrm{POO}_{1 / 2} \mathrm{O}_{2}\right]^{2-}+1\left[\mathrm{POO}_{2 / 2} \mathrm{O}\right]^{-} \\
5 \mathrm{~A}^{+}+\left[\mathrm{TiO}_{5 / 2}\right]^{-}+2\left[\mathrm{POO}_{1 / 2} \mathrm{O}_{2}\right]^{2-}+2\left[\mathrm{POO}_{2 / 2} \mathrm{O}\right]^{-} \\
5 \mathrm{~A}^{+}+\left[\mathrm{TiO}_{6 / 2}\right]^{2-}+3\left[\mathrm{POO}_{2 / 2} \mathrm{O}\right]^{-}\end{array}$ \\
\hline $\begin{array}{l}9 \\
10 \\
11\end{array}$ & $\begin{array}{l}\mathrm{Li}_{5} \mathrm{GeP}_{3} \mathrm{O}_{12}(\mathrm{LJP}) \\
\mathrm{Na}_{5} \mathrm{GeP}_{3} \mathrm{O}_{12}(\mathrm{NJP}) \\
\mathrm{K}_{5} \mathrm{GeP}_{3} \mathrm{O}_{12}(\mathrm{KJP})\end{array}$ & $\begin{array}{l}\text { IR, FTIR } \\
\text { IR, R, FTIR } \\
\text { IR, FTIR }\end{array}$ & $5 \mathrm{~A}^{+}+\left[\mathrm{GeO}_{4 / 2}\right]^{0}+2\left[\mathrm{POO}_{1 / 2} \mathrm{O}_{2}\right]^{2-}+\left[\mathrm{POO}_{2 / 2} \mathrm{O}\right]^{-}$ \\
\hline $\begin{array}{l}12 \\
13\end{array}$ & $\begin{array}{l}\mathrm{Na}_{4} \mathrm{VP}_{3} \mathrm{O}_{12}(\mathrm{NVP}) \\
\mathrm{K}_{4} \mathrm{VP}_{3} \mathrm{O}_{12}(\mathrm{KVP})\end{array}$ & $\begin{array}{l}\text { IR, FTIR } \\
\text { IR }\end{array}$ & $4 \mathrm{~A}^{+}+\left[\mathrm{VOO}_{3 / 2}\right]^{0}+2\left[\mathrm{POO}_{2 / 2} \mathrm{O}\right]^{-}+\left[\mathrm{POO}_{1 / 2} \mathrm{O}_{2}\right]^{2-}$ \\
\hline $\begin{array}{l}14 \\
15\end{array}$ & $\begin{array}{l}\mathrm{Na}_{4} \mathrm{NbP}_{3} \mathrm{O}_{12}(\mathrm{NNP}) \\
\mathrm{K}_{4} \mathrm{NbP}_{3} \mathrm{O}_{12}(\mathrm{KNP})\end{array}$ & $\begin{array}{l}\text { IR, R, FTIR } \\
\text { IR, R, FTIR }\end{array}$ & $4 \mathrm{~A}^{+}+\left[\mathrm{NbO}_{6 / 2}\right]^{-}+3\left[\mathrm{POO}_{2 / 2} \mathrm{O}\right]^{-}$ \\
\hline
\end{tabular}

The spectra are very similar for the $\mathrm{Li}, \mathrm{Na}$ and $\mathrm{K}$ members for a common $\mathrm{B}$ ion but less so for different $\mathrm{B}$ ions for the same alkali ion implying that $\mathrm{B}$ ions play a more significant role than alkali ions in the structure of the glass. It is known that variation of the alkali ion does not influence the higher energy side of the vibrational spectra of alkali metaphosphates ${ }^{25}$. There is no absorption above $1200 \mathrm{~cm}^{-1}$ (at least for glasses 1 to 8 ) (figures 3 and 4) which is the region of $\mathrm{P}=\mathrm{O}$ stretch $^{23,26}$, indicating the absence of long phosphatic chains. However, presence of a band at $740 \mathrm{~cm}^{-1}$ (which is absent in the crystalline NFP or NTP), which can be assigned to the $\mathrm{P}-\mathrm{O}-\mathrm{P}$ bonds ${ }^{27}$, indicates the presence of interconnected $\left[\mathrm{POO}_{m / 2} \mathrm{O}_{k}\right]^{k-}$ tetrahedra in the glass. Several glasses possess bands either at $1027 \mathrm{~cm}^{-1}$ or $1179 \mathrm{~cm}^{-1}$ suggesting the presence of pyrophosphate $\left[\mathrm{P}_{2} \mathrm{O}_{7}\right]^{4-}$ groups ${ }^{23,28,29}$. The absorption at $1380 \mathrm{~cm}^{-1}$, found only in hygroscopic glasses such as LJP (figure 4) can be due to $\mathrm{P}-\mathrm{O}-\mathrm{H}$ deformation ${ }^{23}$ caused by water absorbed by the sample.

The band centred at $1030 \mathrm{~cm}^{-1}$ (glasses 1-3 in figure 3) can be attributed to the stretching modes of the $\mathrm{PO}_{4}$ by comparison with the spectra of crystalline compounds of the same composition. It can be seen that this band is significantly narrower in the spectra of the potassium-containing glasses compared to that of the lithium-containing glasses. The band centre frequency remains unaffected by variation of alkali ions for a given B ion. But the band centre shifts to higher energy for a heavier B ion (substitution of Ga for $\mathrm{Fe}$ in glasses 4 and 5 in figure 3) within a series. This peak is not so evident in other glasses. For example, in titanium-containing glasses this band appears split into two bands centred around $1130 \mathrm{~cm}^{-1}$ and $\sim 900 \mathrm{~cm}^{-1}$ (figure 4). In germanium-containing glasses the resolution is even worse although the peak positions are identifiable. Vanadium-containing glasses (figure 5) are again resolved. However, niobium-containing 


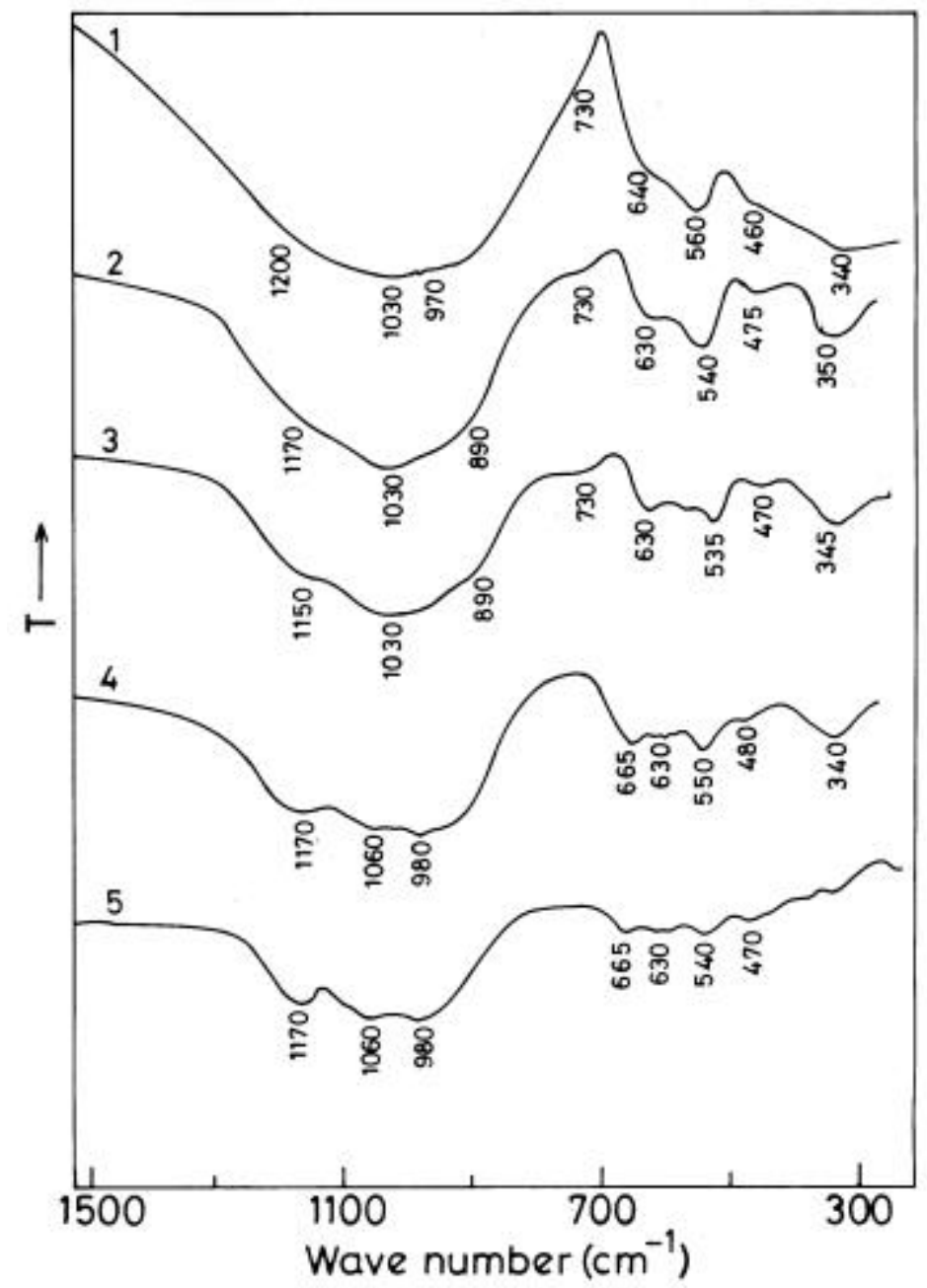

Figure 3. IR spectra of $\mathrm{A}_{3} \mathrm{~B}_{2} \mathrm{P}_{3} \mathrm{O}_{12}$ glasses where $\mathrm{A}=\mathrm{Li}, \mathrm{Na}$ or $\mathrm{K}$ and $\mathrm{B}=\mathrm{Fe}$ or $\mathrm{Ga}$ (the numbering of the glasses is the same as in table 2).

glasses have relatively better defined features. Thus the stretching modes in this region appear to arise from slight differences in structure ( $\mathrm{P}-\mathrm{O}$ bond lengths and $\mathrm{O}-\mathrm{P}-\mathrm{O}$ bond angles) and inequivalence of $\mathrm{PO}_{4}$ groups (see later).

3.2b FTIR spectra: FTIR spectra of the glasses are given in figure 6. In glasses 1-3, the absorption peaks at $640 \mathrm{~cm}^{-1}$ and that at $540 \mathrm{~cm}^{-1}$ together appear to constitute a band. The position of this band corresponds to the asymmetric bending modes of the $\mathrm{PO}_{4}$ ion in the spectra of its crystalline phases. An absorption band is present in this region $\left(500-650 \mathrm{~cm}^{-1}\right)$ in all glasses and is attributable to $\mathrm{O}-\mathrm{P}-\mathrm{O}$ bending modes ${ }^{26,27}$. This band is very sensitive to change of the alkali ion. The energy of this band is the highest for the $\mathrm{Li}$ member and lowest for the $\mathrm{K}$ member. As noted earlier, it is also affected, though to a 


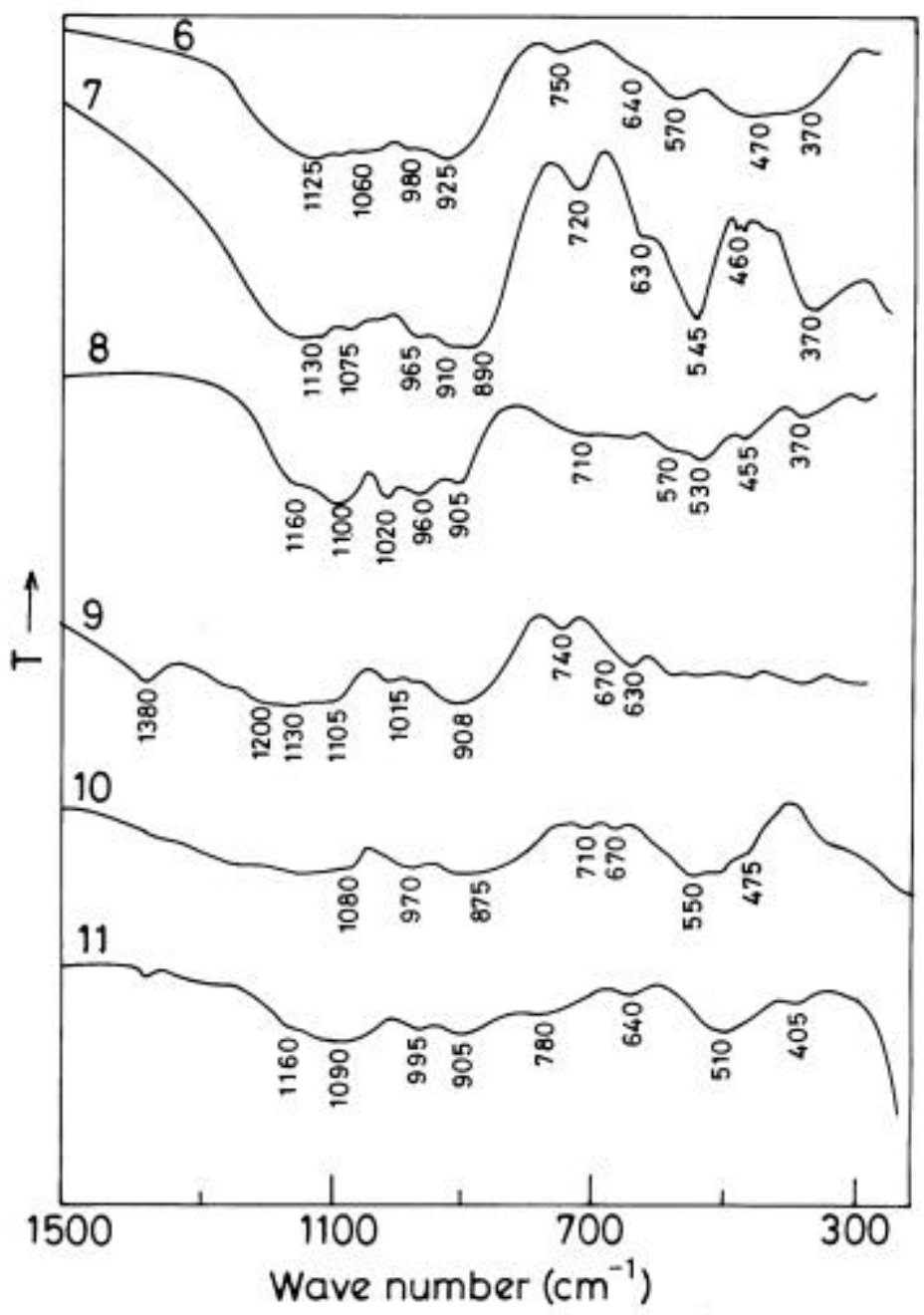

Figure 4. IR spectra of $\mathrm{A}_{5} \mathrm{BP}_{3} \mathrm{O}_{12}$ glasses where $\mathrm{A}=\mathrm{Li}$, $\mathrm{Na}$ or $\mathrm{K}$ and $\mathrm{B}=\mathrm{Ti}$ or $\mathrm{Ge}$ (the exact compositions of the glasses are given in table 2).

lesser extent, by the substitution of heavier B ions within a series (like Fe for Ga). The lighter B ion glass has this band at a lower energy than the heavier B ion member, for the same alkali ion.

The weak band at $\sim 460 \mathrm{~cm}^{-1}$ (figure 6) is also assigned to bending mode of the $\mathrm{PO}_{4}$ tetrahedra ${ }^{26,27,30}$. This band appears very prominently in the infrared absorption spectrum of sodium metaphosphate glass (figure 7), but appears just as a weak band in higher alkali-containing glasses. The presence of this band strongly points towards the network features of phosphate species present in the glasses. The intensity of this band is notably high in the NJP glass. 


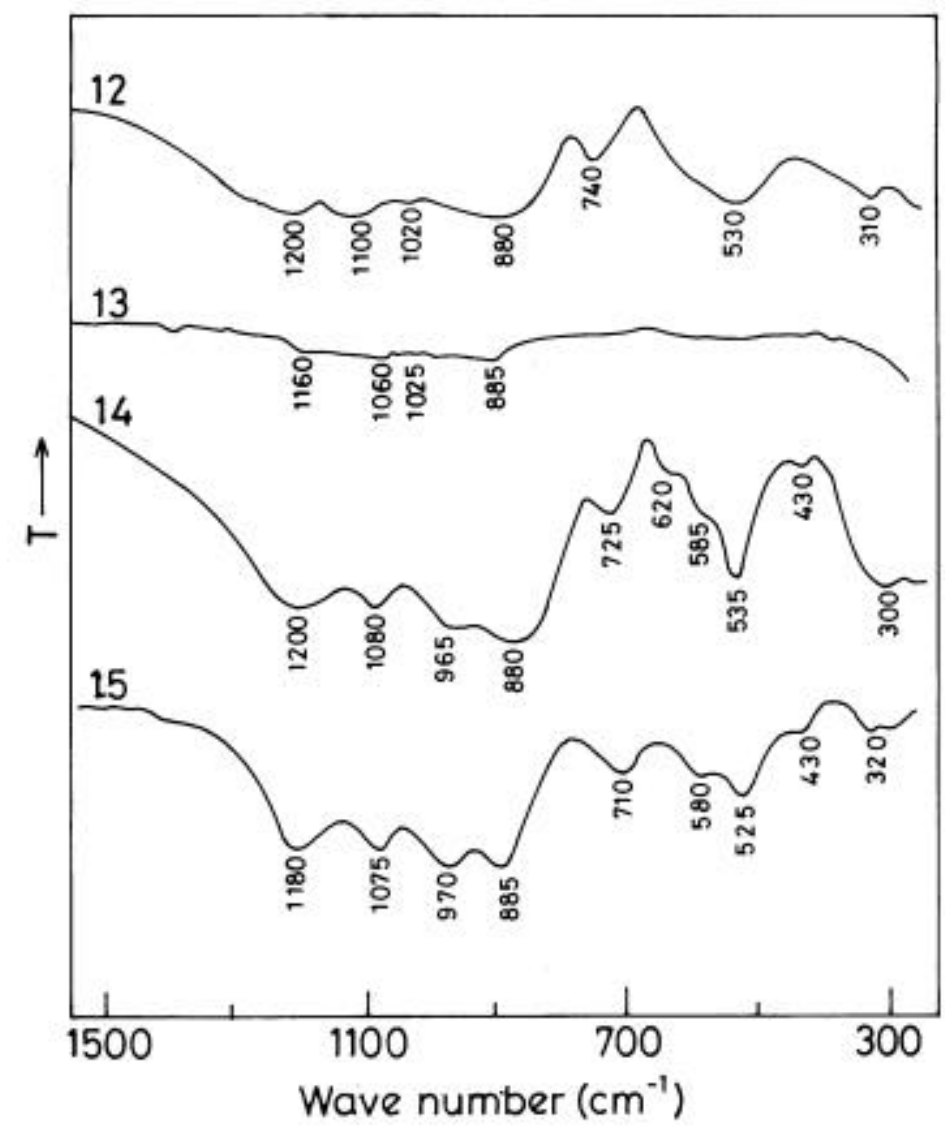

Figure 5. IR spectra of $\mathrm{A}_{4} \mathrm{BP}_{3} \mathrm{O}_{12}$ glasses where $\mathrm{A}=\mathrm{Li}, \mathrm{Na}$ or $\mathrm{K}$ and $\mathrm{B}=\mathrm{V}$ or $\mathrm{Nb}$ (see table 2 for the numbering of the glasses).

The other significant band which occurs below $400 \mathrm{~cm}^{-1}$ in FTIR spectra (figure 6) is attributed to the cage vibrations of the alkali ions. Positions of the alkali ion bands (marked by arrows for easy identification) are affected by the B ion, indicating that the charge on the oxygen ion around $\mathrm{Na}^{+}$is controlled by $\mathrm{B}$ atoms also which constitute part of the network. It is interesting to note that the energies of these bands $\left(\mathrm{Li}^{+} \sim 450 \mathrm{~cm}^{-1}\right.$; $\mathrm{Na}^{+} \sim 245 \mathrm{~cm}^{-1} ; \mathrm{K}^{+} \sim 160 \mathrm{~cm}^{-1}$ ) are higher than in alkali meta phosphate glasses, but more close to those observed in alkali metasilicate glasses ${ }^{25}$. Since the alkali ions are present in cages surrounded by oxygens from both $\left[\mathrm{POO}_{m / 2} \mathrm{O}_{k}\right]^{k-}$ and $\left[\mathrm{BO}_{l / 2}\right]^{n-}$ units, the average negative charge on the cage oxygen atoms is influenced by $\mathrm{B}$ atoms in the structure. In pure metaphosphate glass the average partial charge on oxygen in $\left[\mathrm{POO}_{2 / 2} \mathrm{O}\right]^{-}(-0 \cdot 347)$ is low compared to the charges on the oxygens in $\left[\mathrm{SiO}_{3 / 2} \mathrm{O}\right]^{-}(-0.437)$ (these charges have been calculated using Sanderson's procedure $\left.{ }^{31}\right)$. Thus the charge on oxygen ions in $\left[\mathrm{SiO}_{3 / 2} \mathrm{O}\right]^{-}$ions is higher in the metasilicate glass and this increases the force constant and thereby the cage vibrational frequencies. Charges on oxygens in most $\left[\mathrm{BO}_{l / 2}\right]^{n-}$ are also higher than those in $\left[\mathrm{POO}_{2 / 2} \mathrm{O}\right]^{-}$. Similar numbers of oxygen atoms from $\left[\mathrm{BO}_{l / 2}\right]^{n-}$ and 


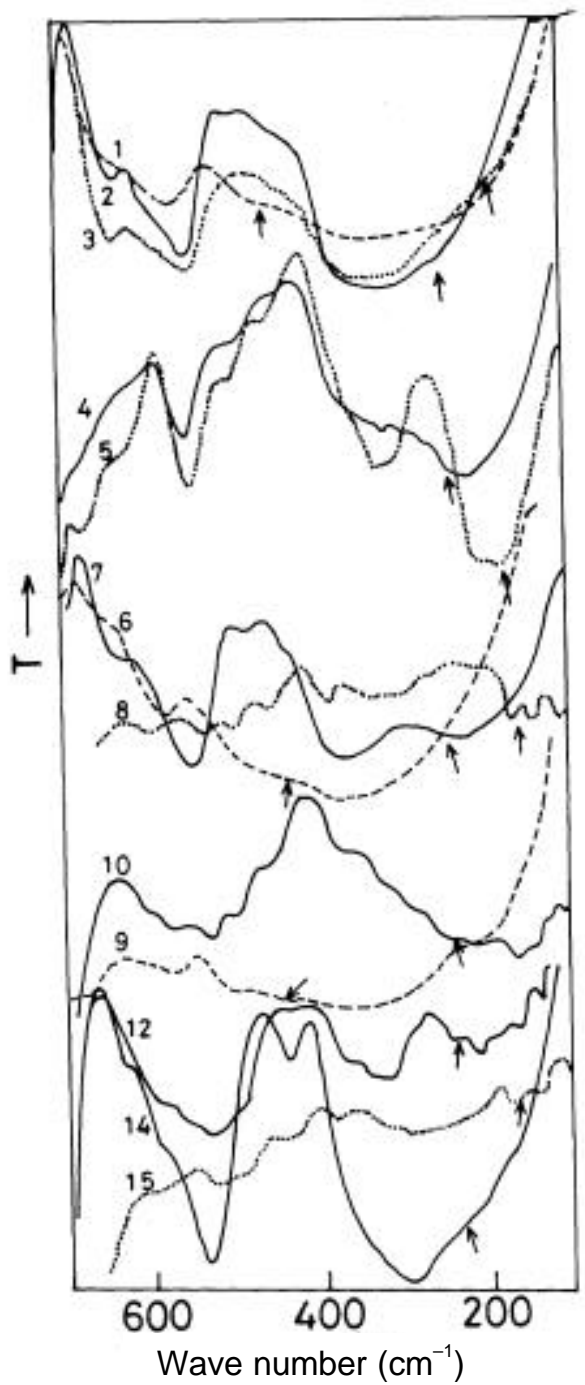

Figure 6. FTIR spectra of the glasses (see table 2 for the numbering of the glasses). The arrows denote the positions of the vibrations bands of the alkali ions' cage.

$\left[\mathrm{POO}_{2 / 2} \mathrm{O}\right]^{-}$are present in the coordination sphere, because the ratio $(\mathrm{B} / \mathrm{P})$ is fixed in these glasses (glasses 6-15). Also the higher charge on the oxygen atoms attached to B increases the average partial charge on oxygens in the cage and renders the $\mathrm{Na}^{+} \ldots \mathrm{O}^{-}$force constant higher. Thus the observed cage vibrational frequencies are also higher than in pure alkali metaphosphate glasses. As expected the intensity of the cage vibrational band increases as alkali ion concentration is increased.

The band at $340 \mathrm{~cm}^{-1}$ is very interesting (figure 6). This band appears broader due to overlap of the cage vibrational band of the alkali ions. The band appears split in the Ga glasses. This band appears at higher energy for the Ti and Ge glasses, but at lower energy 
for the $\mathrm{Nb}$ and $\mathrm{V}$ glasses. The composition dependence of the band position could not be studied quantitatively. The band appears to be unaffected by the B ion mass, since in both $\mathrm{Nb}$ and $\mathrm{V}$ glasses this band appears at $310 \mathrm{~cm}^{-1}$. Since this band is entirely absent in alkali phosphate glasses (figure 7), it is most likely to be related to the $\mathrm{P}-\mathrm{O}-\mathrm{B}$ bending vibrations. The frequency is low for $\mathrm{Fe}$ and $\mathrm{Ga}$ glasses because of the low force constants (low values of charges on $\mathrm{Fe}^{3+}$ and $\mathrm{Ga}^{3+}$ ). But it is unclear as to why the frequency is again low in $\mathrm{V}$ and $\mathrm{Nb}$ glasses.

3.2c Raman spectra: The Raman spectra of the glasses are shown in figure 8 . The Raman spectra could not be obtained for a number of samples because they are either deeply coloured (like the KFP or NVP glasses) or very hygroscopic like the KJP glass. The Raman spectra of the crystalline and glassy NNP ${ }^{13}$ are similar. The spectra are also in very good agreement with literature reports ${ }^{15,19,20}$. The glass spectrum of NTP consists of all the important features present in the spectrum of the crystal. But in the case of NFP,

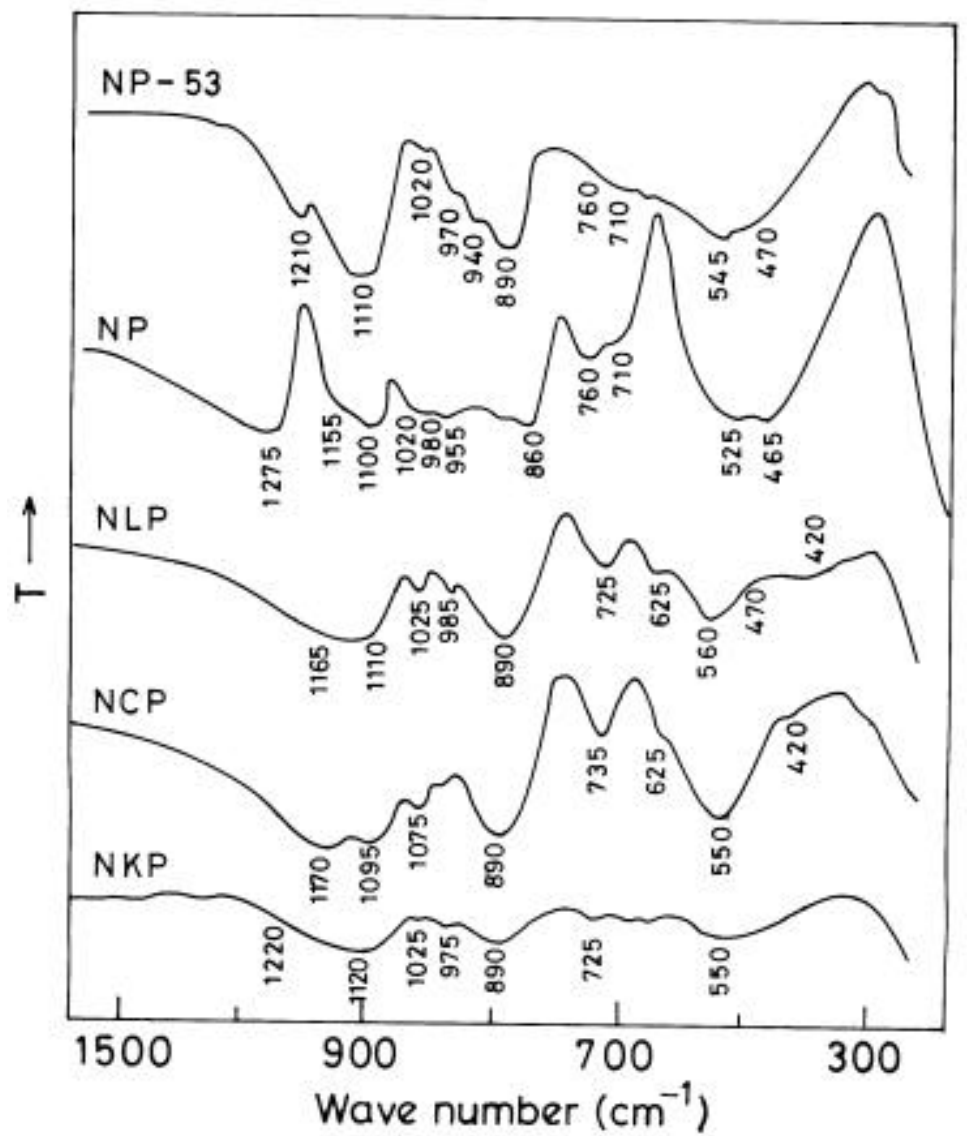

Figure 7. IR absorption spectra of some alkali phosphate glasses. The compositions are NP53 $=5 \mathrm{Na}_{2} \mathrm{O}-3 \mathrm{P}_{2} \mathrm{O}_{5}, \mathrm{NP}=\mathrm{NaPO}_{3}, \mathrm{NLP}=4 \mathrm{Na}_{2} \mathrm{O}-1 \mathrm{Li}_{2} \mathrm{O}-3 \mathrm{P}_{2} \mathrm{O}_{5}, \mathrm{NCP}=4 \mathrm{Na}_{2} \mathrm{O}-$ $1 \mathrm{CuO}-3 \mathrm{P}_{2} \mathrm{O}_{5}, \mathrm{NKP}=5 \mathrm{Na}_{2} \mathrm{O}-1 \mathrm{~K}_{2} \mathrm{O}-3 \mathrm{P}_{2} \mathrm{O}_{5}$. 


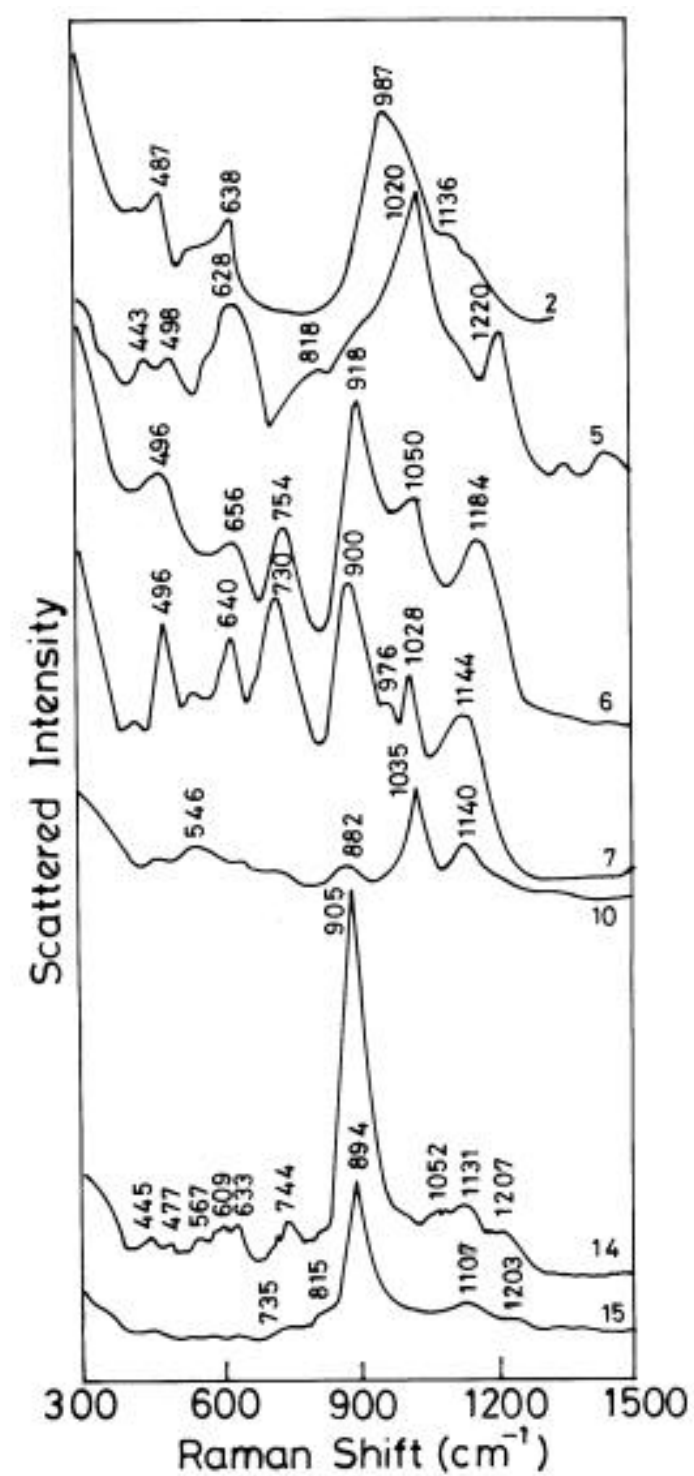

Figure 8. Raman spectra of the glasses (table 2 gives the exact compositions).

some major differences can be seen between the Raman spectra of the glass and the crystal in the $1100 \mathrm{~cm}^{-1}$ region, which arises from the stretching modes of the $\mathrm{PO}_{4}$ units. The implications of these observations are discussed later.

The Raman spectra of the glasses exhibit considerable differences. Here again most differences are found in the region of the $\mathrm{P}-\mathrm{O}$ stretching modes. The highest intensity band in KGP and NJP spectra is observed at $1020 \mathrm{~cm}^{-1}$, which may be assigned to P-O stretching ${ }^{30}$. The bending modes at $638 \mathrm{~cm}^{-1}$ and $487 \mathrm{~cm}^{-1}$ are found in almost all the cases. There are several bands common to both IR and Raman spectra of the glasses. But it is difficult to identify and compare quantitatively the various bands due to their large 
half-widths. An important feature of the Raman spectra is that for the same B ion (say Ti) the spectra of glasses with different alkalis are very similar. But with different B atoms (say $\mathrm{Ge}, \mathrm{Fe}$ and $\mathrm{Nb}$ ) the spectra are significantly different. This again is consistent with the observations made in the previous section.

\subsection{General}

3.3a Evidence for $\left[\mathrm{P}_{2} \mathrm{O}_{7}\right]^{4-}$ species: Some of the systems reported here have been studied using vibrational spectroscopy by other workers also. El Jazouli et al ${ }^{13}$ compared the Raman spectra of $\mathrm{Na}_{4} \mathrm{NbP}_{3} \mathrm{O}_{12}$ glass and crystal, and concluded that the structure of the glass and the crystal are very similar and consistent with NASICON-type structure with distorted and isolated $\mathrm{PO}_{4}$ tetrahedra. Wang et al ${ }^{16}$ from their IR spectroscopic study of NNP glass and crystal concluded that the crystal consisted of pyrophosphate units which were present in the glass also. While Wang et al ${ }^{16}$ attributed the $1175 \mathrm{~cm}^{-1}$ band to pyrophosphate units, Krimi et al ${ }^{15}$ associated the weak $1027 \mathrm{~cm}^{-1}$ stretching mode with $\left[\mathrm{P}_{2} \mathrm{O}_{7}\right]^{4-}$. The spectra of NNP (also KNP) glass in figure 4 are in very good agreement with those of Wang et al ${ }^{16}$. The $1180 \mathrm{~cm}^{-1}$ band due to $\mathrm{P}-\mathrm{O}$ stretching along with the $725 \mathrm{~cm}^{-1}$ band due to $\mathrm{P}-\mathrm{O}-\mathrm{P}$ bending may be considered as evidence for the presence of $\left[\mathrm{P}_{2} \mathrm{O}_{7}\right]^{4-}$ in our glasses as well. Presence of $1175 \mathrm{~cm}^{-1}$ and $715 \mathrm{~cm}^{-1}$ absorption peaks in the crystalline NNP (figure 1) appear therefore to support the conclusion of Wang et al $^{16}$ that crystalline NNP also contains pyrophosphate groups. We may also note that Sales and Chakoumakos ${ }^{32}$ found evidence for the presence of only $\left[\mathrm{P}_{2} \mathrm{O}_{7}\right]^{4-}$ ions in crystalline NNP from high performance liquid chromatography (HPLC) experiments. It would however be difficult to understand how the chemistry of $\mathrm{A}_{x} \mathrm{~B}_{y}\left(\mathrm{PO}_{4}\right)_{3}$ is consistent with the presence of $\left[\mathrm{P}_{2} \mathrm{O}_{7}\right]^{4-}$ groups in either crystalline or glassy form unless there are facile chemical and structural disproportionations of phosphate anions occurring in them. This is possible only when the $\left[\mathrm{BO}_{l / 2}\right]^{n-}$ behave as strong structural entities so that the phosphate moiety is present as meta or ultra phosphate units in the structure. On this basis, the likely types of $\left[\mathrm{BO}_{l / 2}\right]^{n-}$ and the associated phosphate units present in the various NASICON compositions have been listed in table 2. The NASICONs in which $\left[\mathrm{P}_{2} \mathrm{O}_{7}\right]^{4-}$ units can form can be directly inferred from table 2. We may now examine the important spectroscopic features in the light of the suggested disproportionation of phosphate units.

3.3b $A_{3} B_{2} P_{3} O_{12}$ glasses: $\mathrm{Na}_{2} \mathrm{O}-\mathrm{Ga}_{2} \mathrm{O}_{3}-\mathrm{P}_{2} \mathrm{O}_{5}$ glasses were studied by Berthet et al ${ }^{17}$, using IR and Raman spectroscopies. They assigned the band at $600-660 \mathrm{~cm}^{-1}$ in the IR spectrum to the $\mathrm{GaO}_{4}$ groups and the Raman peaks at $636 \mathrm{~cm}^{-1}$ and $350 \mathrm{~cm}^{-1}$ were assigned to $\mathrm{GaO}_{4}$ and $\mathrm{GaO}_{6}$ groups respectively. In alkaline earth gallate glasses, the Raman peaks at $515 \mathrm{~cm}^{-1}$ and $540 \mathrm{~cm}^{-1}$ were assigned to $\mathrm{Ga}-\mathrm{O}-\mathrm{Ga}$ bonds between $\mathrm{GaO}_{4}$ tetrahedra, and the band at $675 \mathrm{~cm}^{-1}$ to the vibrations involving non-bridging oxygens from the $\mathrm{GaO}_{4}$ tetrahedra ${ }^{33-35}$. Clearly $600-660 \mathrm{~cm}^{-1}$ vibrations present in good intensity in KGP (figures 6 and 8) and NGP (figure 6) glasses provide evidence for the presence of $\left[\mathrm{GaO}_{4 / 2}\right]^{-}$groups in our glasses. This is consistent (table 2 ) with the proposed presence of $\left[\mathrm{POO}_{3 / 2}\right]^{0}$ and $\left[\mathrm{POO}_{2 / 2} \mathrm{O}\right]^{-}$units in these glasses. The presence of pronounced shoulders at $\sim 1200 \mathrm{~cm}^{-1}$ due to $\mathrm{P}=\mathrm{O}$, prominent peaks around $650 \mathrm{~cm}^{-1}$ due to modes of $\left[\mathrm{POO}_{3 / 2}\right]^{030}$ (figure 3) and bands at $\sim 540 \mathrm{~cm}^{-1}$ attributable to $\left[\mathrm{GaO}_{4}\right]^{-}$, together confirm the presence of the proposed entities. Absence of absorption between $515 \mathrm{~cm}^{-1}$ and $550 \mathrm{~cm}^{-1}$ (due to $\mathrm{Ga}-\mathrm{O}-\mathrm{Ga})$ also suggests that $\left[\mathrm{GaO}_{4 / 2}\right]^{-}$units in the structure are largely isolated by 
intervening phosphate groups. These phosphate units are again isolated in the structure since $730 \mathrm{~cm}^{-1}$ IR absorption due to $\mathrm{P}-\mathrm{O}-\mathrm{P}$ linkages ${ }^{23}$ are absent. In fact, Tarte et al ${ }^{14}$ have pointed out that the phosphate tetrahedra are essentially isolated in the $\mathrm{Na}_{3} \mathrm{Ga}_{2} \mathrm{P}_{3} \mathrm{O}_{12}$ glass, based on the absence of the above peak.

From the similarities of valences of $\mathrm{Ga}$ and $\mathrm{Fe}$, we should expect Fe-containing glasses to exhibit similar spectroscopic features. However, there is evidence from Mössbauer spectroscopy that $\mathrm{Fe}^{3+}$ is octahedrally coordinated in alkali phosphate glasses ${ }^{36}$. $\mathrm{Fe}^{3+}$ acts more like a modifier in such a coordination and only orthophosphate, $\mathrm{PO}_{4}{ }^{3-}$ ions can be present in the glass as suggested in table 2. The Raman bands at $550 \mathrm{~cm}^{-1}$ and $487 \mathrm{~cm}^{-1}$ (figure 8) support the presence of $\mathrm{PO}_{4}{ }^{3-}$ in the NFP glass ${ }^{37}$. However, presence of the weak IR band at $\sim 730 \mathrm{~cm}^{-1}$ (figure 3) and the Raman shoulder near $1170 \mathrm{~cm}^{-1}$ (figure 8 ) can only be due to the presence of other types of phosphatic species ${ }^{38}$. It is reasonable to expect that $\mathrm{Fe}$, like $\mathrm{Ga}$, occupies tetrahedral positions also, as has been suggested in the literature ${ }^{5,28,29}$. Formation of the $\left[\mathrm{FeO}_{4 / 2}\right]$ unit leads to the formation of $\left[\mathrm{POO}_{3 / 2}\right]$ and $\left[\mathrm{POO}_{2 / 2} \mathrm{O}\right]^{-}$groups as in the case of Ga glasses. However, spectroscopic features due to $\left[\mathrm{POO}_{3 / 2}\right]$ are absent. This, we feel is a consequence of the reaction between $\mathrm{PO}_{4}{ }^{3-}$ and the $\left[\mathrm{POO}_{3 / 2}\right]$ which leads to the formation of $\left[\mathrm{POO}_{2 / 2} \mathrm{O}\right]^{-}$,

$$
\mathrm{PO}_{4}{ }^{3-}+2\left[\mathrm{POO}_{3 / 2}\right] \square 3\left[\mathrm{POO}_{2 / 2} \mathrm{O}\right]^{-} \text {. }
$$

The presence of $\mathrm{Fe}^{3+}$ as $\left[\mathrm{FeO}_{4}\right]$ is also consistent with $530-560 \mathrm{~cm}^{-1}$ absorptions (figures 3 and 6$)^{5,26,28,29,39}$. Vibrations below $450 \mathrm{~cm}^{-1}$ in figure 6 could also be attributed to motions involving $\mathrm{Fe}^{5,26,28,29,39}$.

Whenever $\left[\mathrm{POO}_{2 / 2} \mathrm{O}\right]^{-}$groups are present in glass-forming melts an equilibrium of the kind,

$$
4\left[\mathrm{POO}_{2 / 2} \mathrm{O}\right]^{-} \square 2\left[\mathrm{POO}_{3 / 2}\right]+\left[\mathrm{P}_{2} \mathrm{O}_{7}\right]^{4-},
$$

may be expected to be established ${ }^{40}$. Reactions (1) and (2) can be combined to

$$
4 \mathrm{PO}_{4}{ }^{3-}+2\left[\mathrm{POO}_{3 / 2}\right] \square 3\left[\mathrm{P}_{2} \mathrm{O}_{7}\right]^{4-} \text {. }
$$

A strong depletion of $\left[\mathrm{POO}_{3 / 2}\right]$ units is expected at the expense of which $\left[\mathrm{POO}_{2 / 2} \mathrm{O}\right]^{-}$and $\left[\mathrm{P}_{2} \mathrm{O}_{7}\right]^{4-}$ species are produced. While cooling the glass-forming melts there is a likely thermodynamic motivation in the system for the above reaction because it decreases the number of species present and helps the system to eschew configurational entropy, which it should. Therefore, Fe-containing glasses should also contain pyrophosphate units. The peaks at $\sim 1170 \mathrm{~cm}^{-1}(\mathrm{P}=\mathrm{O}$ stretching $)$ and $730 \mathrm{~cm}^{-1}(\mathrm{P}-\mathrm{O}-\mathrm{P} \text { stretching })^{26}$ in $\mathrm{Fe}-$ containing glasses (figures 3 and 8 ) support this view.

3.3c $A_{5} \mathrm{BP}_{3} \mathrm{O}_{12}$ glasses: In Ti-containing glasses a strong Raman band near $900 \mathrm{~cm}^{-1}$ has been thought to arise from $\left[\mathrm{TiO}_{4}\right]$ groups ${ }^{34,41}$. Recently Krimi et al ${ }^{15}$ have assigned the band at $750 \mathrm{~cm}^{-1}$ and $905 \mathrm{~cm}^{-1}$ to $\left[\mathrm{TiO}_{6}\right]$ and $\left[\mathrm{TiO}_{5}\right]$ entities respectively. The particularly strong IR absorption of the NTP glass (figure 4) at $545 \mathrm{~cm}^{-1}$ and the Raman bands at $640 \mathrm{~cm}^{-1}$ (figure 8) may be taken as indication of octahedrally coordinated $\mathrm{Ti}$, whereas the strong Raman peak near $750 \mathrm{~cm}^{-1}$ in the Raman spectra of LTP and NTP (figure 8) may be assigned to tetrahedrally coordinated $\mathrm{Ti}$ in comparison with the literature reports on crystalline titanates ${ }^{42}$. As a result of the tendency of titanium to form 
tetrahedral $\left[\mathrm{TiO}_{4 / 2}\right]^{0}$, square pyramidal $\left[\mathrm{TiO}_{5 / 2}\right]^{-}$and octahedral $\left[\mathrm{TiO}_{6 / 2}\right]^{2-}$ units, several types of phosphate units are also expected to form (table 2). Thus the interpretation of the vibrational spectra of LTP and NTP glasses is quite difficult. $\left[\mathrm{TiO}_{4 / 2}\right]^{0}$ units readily lead to the formation of pyrophosphate units,

$$
\mathrm{Na}_{5} \mathrm{TiP}_{3} \mathrm{O}_{12} \rightarrow 5 \mathrm{Na}^{+}+\left[\mathrm{TiO}_{4 / 2}\right]^{0}+\left[\mathrm{POO}_{2 / 2} \mathrm{O}\right]^{-}+\left[\mathrm{POO}_{1 / 2} \mathrm{O}_{2}\right]^{2-}
$$

Peaks in IR (and also in Raman) in $1020-1100 \mathrm{~cm}^{-115}$ region along with features in the region of $700-750 \mathrm{~cm}^{-1}$ (P-O-P linkage) support the presence of $\left[\mathrm{P}_{2} \mathrm{O}_{7}\right]^{4-}$. $\left(\left[\mathrm{TiO}_{4}\right]\right.$ vibrations also contribute to the absorption in this region.) There is no absorption at $\sim 665 \mathrm{~cm}^{-1}$ and therefore $\left[\mathrm{POO}_{3 / 2}\right]$ units are absent supporting the occurrence of the above reaction.

Ge has the same valency as Ti and germanium glasses also exhibit very similar IR spectra. Only $\left[\mathrm{GeO}_{4 / 2}\right]^{0}$ and $\left[\mathrm{GeO}_{6 / 2}\right]^{2-}$ species are known in literature. Presence of 1080 $1100 \mathrm{~cm}^{-1}$ band together with $740-780 \mathrm{~cm}^{-1}$ band (figure 4) (except in NJP where $710 \mathrm{~cm}^{-1}$ peak is seen) again suggests presence of pyrophosphate units. Further the signature frequency of tetrahedrally coordinated $\mathrm{Ge}$ at $\sim 900 \mathrm{~cm}^{-143}$ present in all $\mathrm{Ge}$ glasses and absence of IR bands at $580-600 \mathrm{~cm}^{-1}$ (figure 4), together with the absence of a Raman band at $710 \mathrm{~cm}^{-1}$ (figure 8) attributable to octahedrally coordinated $\mathrm{Ge}^{43,44}$, suggest that $\mathrm{Ge}$ is present only in $\left[\mathrm{GeO}_{4 / 2}\right]^{0}$ units.

3.3d $\mathrm{A}_{4} \mathrm{BP}_{3} \mathrm{O}_{12}$ glasses: Although vanadium has the same valency as $\mathrm{Nb}$, it tends to form $\left[\mathrm{VOO}_{3 / 2}\right]$ units in glass ${ }^{45}$, similar to phosphorus which forms $\left[\mathrm{POO}_{3 / 2}\right]$ units. Unfortunately the IR spectra of vanadium-containing glasses in this work are poorly resolved. Presence of a peak at $740 \mathrm{~cm}^{-1}$ can be associated with $\left[\mathrm{VOO}_{3 / 2}\right]$ units in addition to $\mathrm{P}-\mathrm{O}-\mathrm{P}$ linkages ${ }^{45}$. However vanadium glass should also contain pyrophosphate units (table 2) and the presence of $1100 \mathrm{~cm}^{-1}$ (NVP) and $1060 \mathrm{~cm}^{-1}$ (KVP) support this possibility.

3.3e Pyrophosphate units and spectra of crystalline $N N P:{ }^{31} \mathrm{P}$ MAS NMR evidence clearly points to the presence of at least two distinguishable phosphate units in crystalline $\mathrm{NNP}^{46,47}$. But only one (averaged) ${ }^{31} \mathrm{P}$ resonance was identified in the glass, where it is easy to visualize the formation of pyrophosphate units because in the melt an equilibrium of the type represented by $(2)(\$ 3.3 b)$ can occur. Structurally $\left[\mathrm{P}_{2} \mathrm{O}_{7}\right]^{4-}$ is an apically fused ditetrahedron. One can visualize the occurrence of a structural and chemical disproportionation of the type represented by (2) even in crystalline compounds like NNP (or NTP) resulting in two types of phosphate species. Topochemical constraints fix the positions of the phosphate units in the structure in the lattice and high resolution magic angle spinning nuclear magnetic resonance (HR MAS NMR) can distinguish between them even though the chemical shift difference between them is small. But the two ${ }^{31} \mathrm{P}$ signals possibly get merged into a single NMR peak of larger FWHM in the glass. Presence of $\left[\mathrm{POO}_{3 / 2}\right]$ units in the glasses is suggested in the IR absorption features at $>1200 \mathrm{~cm}^{-1}$ in NNP (figure 5) and several other glasses (figures 3 and 4) which is due to $\mathrm{P}=\mathrm{O}$ stretching. Features at $\sim 650 \mathrm{~cm}^{-1}$ due to $\mathrm{P}=\mathrm{O}$ bending further confirm the presence of $\left[\mathrm{POO}_{3 / 2}\right]$ groups in the glass ${ }^{27}$. The absorption peak at $530 \mathrm{~cm}^{-1}$ (figure 5) can be attributed to $\mathrm{Nb}-\mathrm{O}$ vibrations ${ }^{16}$. A $525 \mathrm{~cm}^{-1}$ peak is particularly prominent in the FTIR spectrum of NNP which again supports this conclusion. The strong absorption peak at $\sim 900 \mathrm{~cm}^{-1}$ present in IR and Raman spectra of the $\mathrm{Nb}$ glasses may include contributions 
from the $\left[\mathrm{NbO}_{6}\right]$ vibrations ${ }^{13}$. Spectroscopic features of KNP and NNP glasses (figures 5 and 6) are very similar.

Two aspects of the literature reports regarding the vibrational spectrum of NASICON glasses need to be considered further. El Jazouli et $^{1 l^{13}}$ reported that the crystal and glass structures are very similar on the basis of Raman spectroscopic studies but it was found that glass and crystal do have distinguishable structures on the basis of ${ }^{31}$ P MAS NMR studies. However, studies of Wang et al ${ }^{16}$, HPLC studies of Sales and Chakoumakos ${ }^{32}$ and the present spectroscopic studies together suggest that pyrophosphate units are likely to be present in both crystalline and glassy NASICONs containing Nb. Formation of pyrophosphate units can be visualized only through the reaction represented by (2). It is possible only if there is dynamic switching of bonds among the tetrahedral phosphate units surrounding the B ions in the crystal structure. Four phosphate tetrahedral units, (2), in close proximity can switch the bonds forming one pyrophosphate unit and two 3connected $\left[\mathrm{POO}_{3 / 2}\right]$ units. This requires only a slight reorientation of the four phosphate tetrahedra in such a way that a binary ditetrahedral unit is formed which snaps all its other links forming the $\left[\mathrm{P}_{2} \mathrm{O}_{7}\right]^{4-}$ unit. At the same time the other two units form two additional links resulting in the formation of $\left[\mathrm{POO}_{3 / 2}\right]$ units. Thus there is both charge and bond conservation. At ordinary temperatures, a dynamical bond switching as envisaged here can still enable distinguishing the different phosphate units by NMR experiments if the time scales of switching are less than $10 \mathrm{~ns}$. Similarly, presence of P-O-P linkages characteristic of pyrophosphates, are also identified from IR spectra in which time constants are less than $10 \mathrm{~ns}$. Secondly, association of $1175 \mathrm{~cm}^{-1}$ IR absorption features with pyrophosphate units ${ }^{16}$ does not appear to be unequivocal. In our investigation, we found that formation of pyrophosphate units was always associated with the $1027 \mathrm{~cm}^{-1}$ absorption as suggested by Krimi et al ${ }^{15}$. An absorption feature around $650 \mathrm{~cm}^{-1}$ (figures $3-5$ ) attributable to $\left[\mathrm{POO}_{3 / 2}\right]$ units was also present in many spectra since the latter forms together with $\left[\mathrm{P}_{2} \mathrm{O}_{7}\right]^{4-}$ units.

\section{Conclusions}

Vibrational properties of several phosphates with NASICON chemistry have been examined using IR, Raman and FTIR spectroscopies considered together, the vibrational spectra of glasses reveal the following.

(1) The IR spectra is dominated by the vibrational properties of phosphates which also provide vital clues to understand the structure of the glasses.

(2) Phosphate units establish equilibria among various phosphatic species through disproportionation reactions which conserve both charges and bonds.

(3) B atoms seem to be present in different possible coordinations to oxygen atoms and generally tend to have lower coordination numbers with higher covalency of bonding. Different phosphatic species are therefore present in glasses (table 2). Although the spectra are dominated by vibrational features due to phosphate ions, B ions also register their presence in the middle region of $400-800 \mathrm{~cm}^{-1}$. Notable in the spectra shown in figures $3-5$ are the specific peaks due to $\mathrm{Fe}\left(530-550 \mathrm{~cm}^{-1}\right)$, Ga $\left(600-675 \mathrm{~cm}^{-1}\right)$ and $\mathrm{Ti}\left(905 \mathrm{~cm}^{-1}, \quad 750 \mathrm{~cm}^{-1}\right.$ and $\left.640 \mathrm{~cm}^{-1}\right)$ containing oxypolyhedra. Alkali ion vibration in oxygen cages have been identified in FTIR spectra. However, this region of spectrum is complicated by the excitation of external modes of the various structural groups present in the glasses. Thus the 
vibrational spectroscopic investigations have helped identify unique structural features of glasses with NASICON chemistry.

\section{References}

1. Hong H Y-P 1976 Mater. Res. Bull. 11173

2. Goodenough J B, Hong H Y-P and Kafalas J A 1976 Mater. Res. Bull. 11203

3. Veríssimo C, Garrido F M S, Alves O L, Paloma Calle, Martínez-Juárez A, Iglesias J E and Rojo J M 1997 Solid State Ionics 100127

4. Prakash G V, Nachimuthu P, Vithal M and Jagannathan R 1999 Bull. Mater. Sci. 22121

5. Catti M 2001 J. Solid State Chem. 156305

6. Sobha K C and Rao K J 1995 Solid State Ionics 81145

7. Sobha K C and Rao K J 1995 Proc. Indian Acad. Sci. (Chem. Sci.) 107573

8. Sobha K C and Rao K J 1996 J. Non-Cryst. Solids 20152

9. Sobha K C and Rao K J 1996 J. Phys. Chem. Solids 571263

10. Sobha K C and Rao K J 1996 J. Solid State Chem. 121197

11. Boilot J P, Collin G and Comes R 1983 J. Solid State Chem. 5091

12. Muthupari S and Rao K J 1994 Chem. Phys. Lett. 223133

13. El Jazouli A, Parent C, Dance J M, Le Flem G, Hegenmuller P and Viala J C 1988 J. Solid State Chem. 74377

14. Tarte P, Rulmont A, Liégeois-Duyckaerts M, Cahay R and Winand J M 1990 Solid State Ionics $\mathbf{4 2} 177$

15. Krimi S, El Jazouli A, Rabardel L, Couzi M, Mansouri I and Flem G Le 1993 J. Solid State Chem. 102400

16. Wang B, Greenblatt M and Yan J 1994 Solid State Ionics 6985

17. Berthet P, Bretey E, Berthon J, Yviore F d', Belkebir A, Rulmont A and Gilbert B 1994 Solid State Ionics 70/71 476

18. Hagman L and Kierkegaard P 1968 Actachem. Scand. 221822

19. Barj M, Perthuis $\mathrm{H}$ and Colomban $\mathrm{Ph} 1983$ Solid State Ionics $9 \& 10845$

20. Barj M, Perthuis H and Colomban Ph 1983 Solid State Ionics $9 \& 10157$

21. Tarte P, Rulmont A and Merckaert-Ansay C 1986 Spectrochim. Acta $\mathbf{A 4 2} 1009$

22. Rochère M de la, Yvoire F d', Collin G, Comès R and Boilot J P 1983 Solid State Ionics $9 \& 10$ 825

23. Corbridge D E C and Lowe E J 1954 J. Chem. Soc. 493

24. Exarhos G J and Risen W M Jr. 1972 Solid State Commun. 11755

25. Exarhos G J, Miller P J and Risen W M Jr. 1974 J. Chem. Phys. 604145

26. Osaka A, Takahashi K and Ikeda M 1984 J. Mater. Sci. 336

27. Wong J and Angell C A 1976 Glass structure by spectroscopy (New York: Marcel Dekker)

28. Moguš-Milankov́ic A, Pivac B, Fúric and Day D E 1997 Phys. Chem. Glasses 3874

29. Pivac B, Moguš-Milankóvic A and Day D E 1998 J. Non-Cryst. Solids 22641

30. Botto I L and Minelli G 1986 J. Phys. Chem. Solids 47259

31. Sanderson R T 1983 Polar covalence (New York: Academic Press)

32. Sales B C and Chakoumakos B C 1993 J. Solid State Chem. 105406

33. Sakka S, Kozuka H, Fukumi K and Miyaji F 1990 J. Non-Cryst. Solids 123176

34. Tourtin F, Armand P, Ibanez A, Manteghetti A and Philippot E 1997 Thin Solid Films 307 43

35. Tourtin F, Armand P, Ibanez A, Tourillon G and Philippot E 1998 Thin Solid Films 322 85

36. Nishida T, Shiotsuki T and Takashima Y 1981 J. Non-Cryst. Solids 43115

37. Nelson C and Tallant D R 1985 Phys. Chem. Glasses 26119

38. Nelson B N and Exarhos G J 1979 J. Chem. Phys. 712739

39. Gabelica-Robert M and Tarte P 1982 J. Mol. Struct. 79251

40. Ananthraj S and Rao K J 1991 Proc. Indian Acad. Sci. (Chem. Sci.) 103655

41. Bobovich Ya S 1962 Opt. Spectrosc. 13274

42. Furukawa T and White W B 1979 Phys. Chem. Glasses 2069

43. Verweij H and Buster J H J M 1979 J. Non-Cryst. Solids 3481 
44. Kumar S, Murugavel S and Rao K J 2001 J. Phys. Chem. B105 5862

45. Muthupari S, Prabakar S and Rao K J 1994 J. Phys. Chem. 982646

46. Prabakar S, Rao K J and Rao C N R 1991 J. Mater. Res. 6285

47. Prabakar S, Rao K J and Rao C N R 1991 Mater. Res. Bull. 26805 